\title{
Cloning and DNA sequence analysis of a bacteriocin gene of Serratia marcescens
}

\author{
M. Beatriz Viejo, Domingo Gargallo, $†$ Santiago Ferrer, Josefina Enfedaque and \\ Miguel ReGUE**
}

Department of Microbiology and Parasitology, Health Sciences Division, Faculty of Pharmacy, University of Barcelona, Barcelona 08028, Spain

(Received 20 January 1992; revised 3 April 1992; accepted 14 April 1992)

\begin{abstract}
Serratia marcescens $\mathbf{N 2 8 b}$ synthesized and secreted a bacteriocin, with a molecular mass of $\mathbf{4 5} \mathrm{kDa}$, which was capable of inhibiting the growth of Escherichia coli. The expression of this bacteriocin was negligible unless induced with mitomycin $C$. The genes encoding the bacteriocin were cloned in plasmid pBR328. $E$. coli harbouring recombinant plasmid pBA189 or pBA289 expressed the Serratia marcescens $\mathbf{N} 28$ b bacteriocin. The nucleotide sequence of the bss gene (Serratia marcescens $\mathbf{N 2 8 b}$ bacteriocin structural gene) was determined. The predicted amino acid sequence of the carboxy-terminal part of the bacteriocin $28 \mathrm{~b}$ had a high degree of similarity to the poreforming domains of colicins A, E1, B, N, Ia and Ib.
\end{abstract}

\section{Introduction}

Most studies on protein excretion in Gram-negative bacteria have been carried out in Escherichia coli, although this bacterium appears to be rather restricted in its ability to secrete proteins into the extracellular medium. From these studies two models for protein export have emerged: (i) proteins are synthesized as precursors with a signal peptide essential for proper protein secretion (Oliver, 1985; Regué \& Wu, 1988); (ii) other exported proteins are synthesized without a recognizable signal peptide and their release is accomplished by one or more helper proteins (e.g. $\alpha$-haemolysin, colicins A, E1, etc.) (Pugsley, 1988; De Graaf \& Oudega, 1986).

So far, the best known colicins are encoded by colicinogenic plasmids. Usually, an operon containing three genes is involved in colicin synthesis and release. These genes are: a structural gene, an immunity protein gene and a gene coding for a bacteriocin release protein.

* Author for correspondence. Tel. 3-3309061; fax 3-4908274; e-mail ubampp01@ebcescal . bitnet.

$†$ Present address: Glaxo Research, Parque Tecnologico de Madrid, 28760 Tres Cantos, Spain.

\footnotetext{
The nucleotide and amino acid sequence data reported in this paper have been submitted to EMBL and have been assigned the accession number X62454.
}

The bacteriocin release protein is a membrane polypeptide which is essential for colicin release (De Graaf \& Oudega, 1986). The transcription of colicin operons is normally repressed by the LexA protein. This protein regulates the expression of the genes involved in the 'SOS' response (Walker, 1987). Little is known about the mechanisms of bacteriocin release in enterobacteria other than E. coli.

Serratia marcescens has been shown to produce bacteriocins upon induction with ultraviolet light and these bacteriocins have been used in typing $S$. marcescens isolates (Traub, 1980). Foulds \& Shemin (1969) and Foulds (1972) isolated and characterized bacteriocin L from $S$. marcescens. Nevertheless, little is known about the genetic organization and release mechanisms of $S$. marcescens bacteriocins. In this work, the cloning of the genes coding for the $S$. marcescens $\mathrm{N} 28 \mathrm{~b}$ bacteriocin in pBR328 and the nucleotide sequence of the putative bacteriocin structural gene are reported.

\section{Methods}

Bacterial strains and media. $S$. marcescens $\mathrm{N} 28 \mathrm{~b}$ has been described previously (Gargallo-Viola, 1989). E. coli $5 \mathrm{~K} \mathrm{~F}^{-} r_{\mathrm{k}}^{-} m_{\mathrm{k}}^{-} r p s L$ thr thi leu lacZ (Juárez et al., 1984) was used as recipient for the genomic library of $S$. marcescens. E. coli XL1-Blue (Bullock et al., 1987) was used in subcloning experiments with plasmid pSK (Bluescript II SK from Stratagene) as vector. All strains were grown on Trypticase Soy Broth (TSB) or Trypticase Soy Agar (TSA). Ampicillin $\left(25 \mu \mathrm{g} \mathrm{ml}^{-1}\right)$ and 


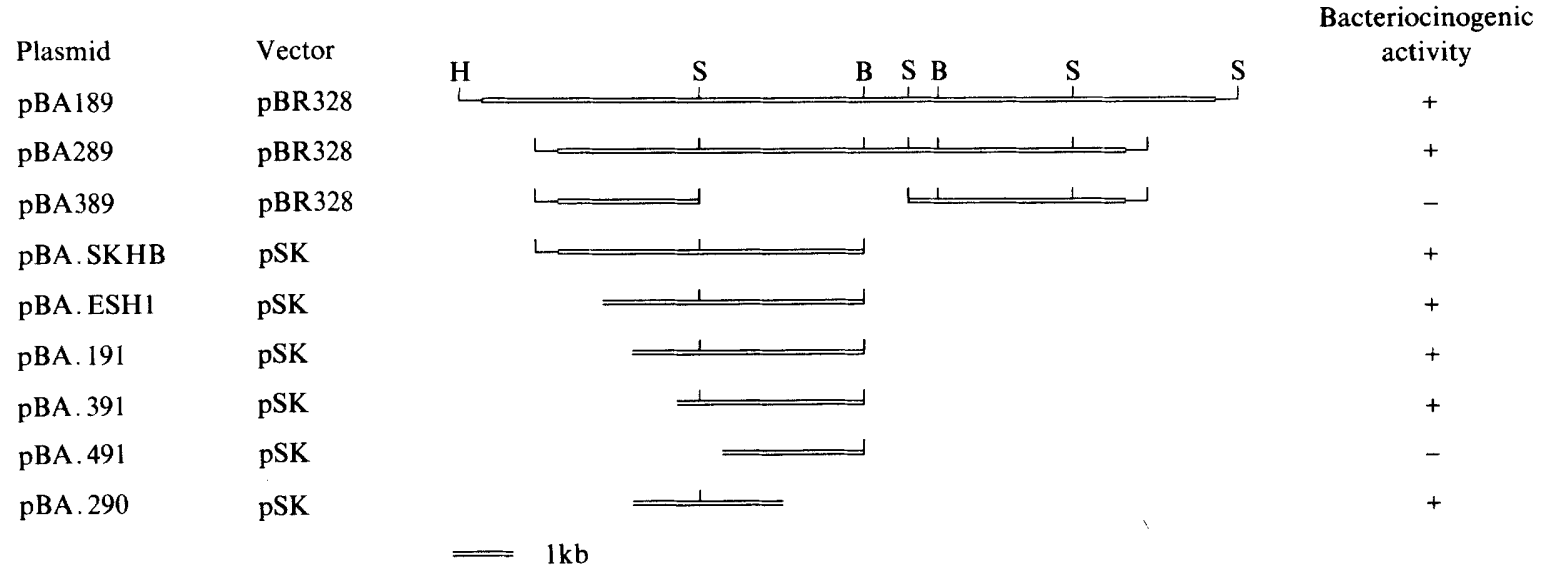

Fig. 1. Restriction endonuclease map of the cloned bacteriocin DNA. Abbreviations: H, HindIII; S, SaII; B, BgIII. The production of bacteriocin by $E$. coli harbouring recombinant plasmids was determined by the agar overlay test (Pugsley \& Oudega, 1987) using E. coli $5 \mathrm{~K}(\mathrm{pBR} 328)$ as indicator strain.

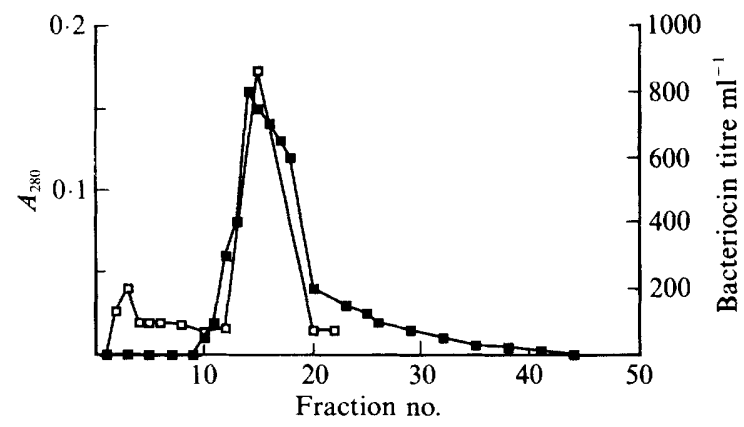

Fig. 2. SP-Sephadex chromatography of void volume fractions from a QAE-Sephadex column. The column was eluted with $50 \mathrm{~mm}$-phosphate buffer ( $\mathrm{pH} 8 \cdot 0$ ) containing $0 \cdot 1 \mathrm{M}-\mathrm{NaCl}$. Bacteriocin peak fractions were pooled, dialysed and lyophilized. $\square, A_{280} ; \square$, bacteriocin titre.

chloramphenicol $\left(25 \mu \mathrm{g} \mathrm{ml}^{-1}\right)$ were added to the media when needed. For the induction of bacteriocin synthesis, mitomycin $\mathrm{C}(0 \cdot 2$ and $2.0 \mu \mathrm{g}$ $\mathrm{ml}^{-1}$ for $E$. coli and $S$. marcescens, respectively) was added to cultures at a culture $\mathrm{OD}_{660}$ of 0.5 , and the cultures were grown for a further $2 \cdot 5 \mathrm{~h}$. The bacteriocin was harvested as previously described for bacteriocin L (Foulds \& Shemin, 1969).

Bacteriocin assay. The production of bacteriocin on solid medium (TSA) was determined by the agar overlay test (Pugsley \& Oudega, 1987). To quantify bacteriocin activity, twofold serial dilutions of bacteriocin preparations were placed on fresh TSA plates inoculated with $200 \mu$ lof an overnight culture of the indicator strain. The titre of bacteriocin activity was defined as the reciprocal of the largest dilution able to inhibit growth of $E$. coli.

Partial bacteriocin purification. Crude preparations of bacteriocin were subjected to QAE-Sephadex and SP-Sephadex chromatography. Fractions containing bacteriocinogenic activity were subjected to SDSPAGE to determine the apparent molecular mass of the bacteriocin.

Construction of the genomic library. Isolation of total DNA, partial digestion with Sau3A and ligation to BamHI-cut pBR328 DNA was (a)

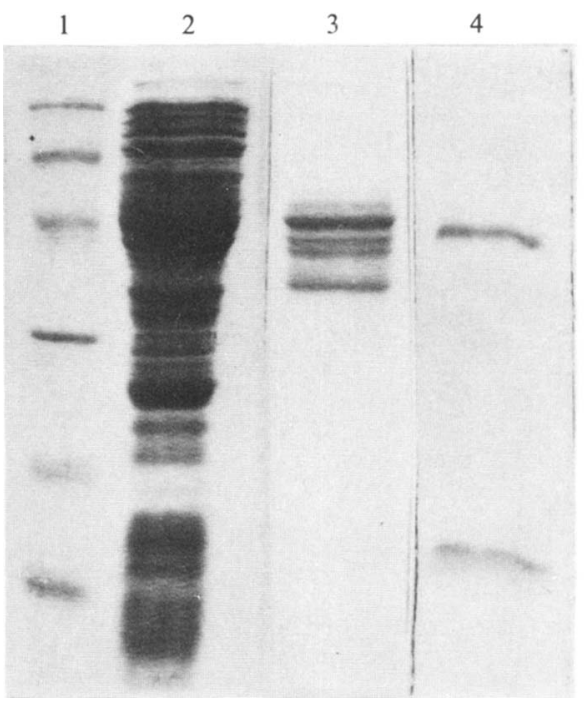

(b)

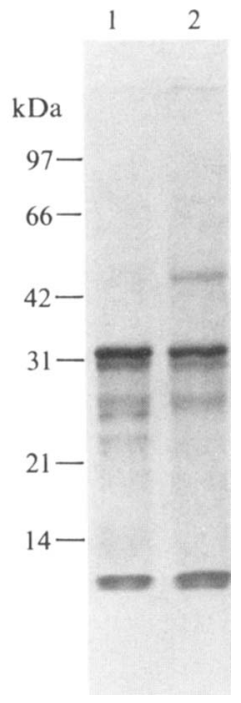

Fig. 3. (a) SDS-PAGE of a concentrated crude extracellular bacteriocin preparation (lane 2), the eluate from a polyacrylamide slice containing bacteriocinogenic activity (lane 3 ), bacteriocinogenic peak fractions from the SP-Sephadex column (lane 4) and molecular mass standards (lane 1: phosphorylase b, $97.4 \mathrm{kDa}$; bovine serum albumin, $66.2 \mathrm{kDa}$; ovalbumin, $42.6 \mathrm{kDa}$; carbonic anhydrase, $31 \mathrm{kDa}$; soybean trypsin inhibitor, $21.5 \mathrm{kDa}$; lysozyme, $14.4 \mathrm{kDa}$ ). (b) SDS-PAGE of ${ }^{[35}$ S $]$ methionine-labelled products of an in vitro transcription/translation coupled system. Lane 2 , in vitro products encoded by pBA. 290 DNA; lane 1 , in vitro products encoded by pSK DNA. The $31 \mathrm{kDa}$ polypeptide corresponds to the TEM- $\beta$-lactamase encoded by PSK.

done as described by Maniatis et al. (1982). Standard methods were used to determine the restriction map of the recombinant plasmids and for the construction of subclones in plasmid pBR328 and pSK (Bluescript II SK from Stratagene). 


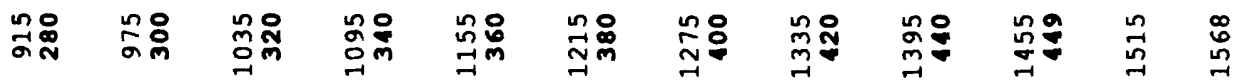

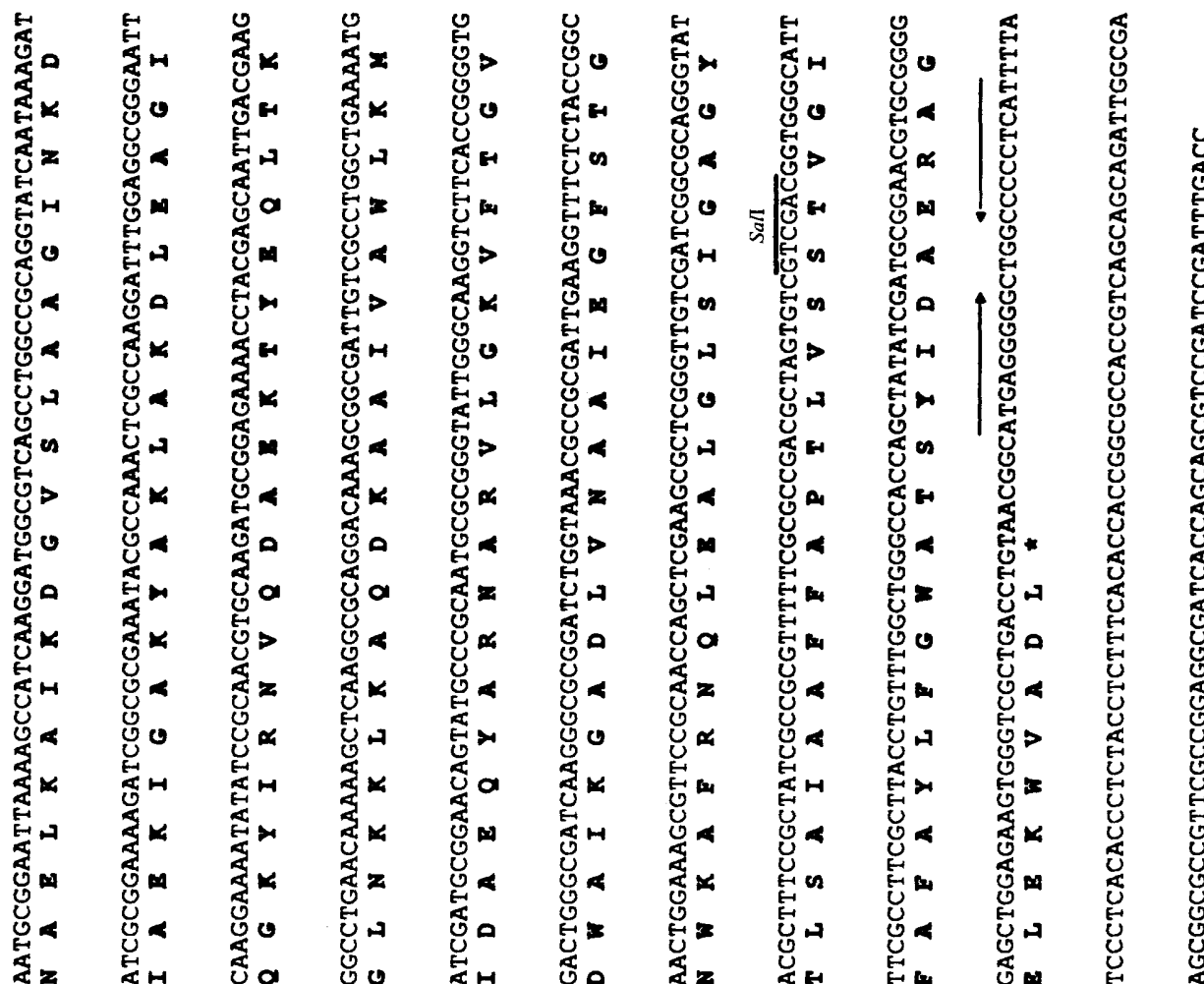

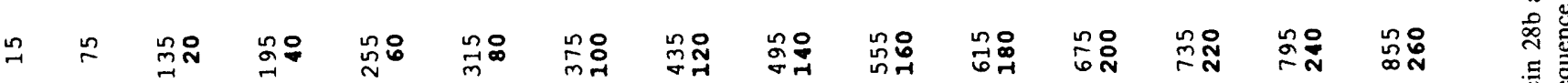

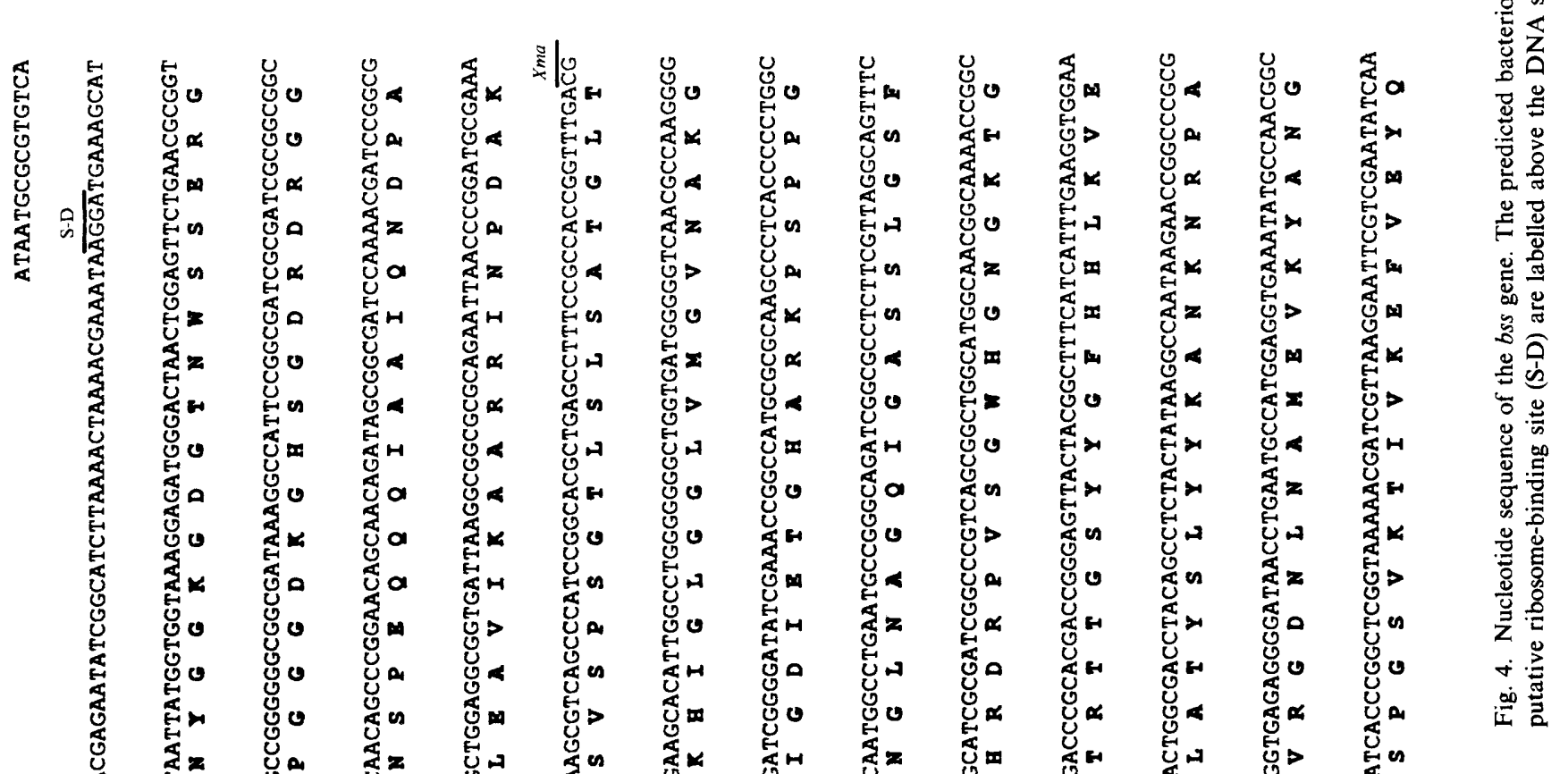


Construction of unidirectional deletions. A $6.5 \mathrm{kbp}$ HindIII-BgIII DNA fragment from pBA289 insert was subcloned in the pSK vector. The resulting plasmid (pBA.SKHB) was digested with KpnI and HindIII and a set of unidirectional deletions was constructed using an ExoIII/Mung bean nuclease deletion kit (Stratagene). The shortest subclone still retaining bacteriocinogenic activity (pBA.191) was digested with $S a c I$ and $\mathrm{XbaI}$ and another set of unidirectional deletions was constructed.

DNA-directed protein synthesis in vitro. In vitro transcription/ translation was carried out by using [ ${ }^{35}$ S $]$ methionine from (Amersham) with the DNA-directed transcription/translation kit (Amersham), as instructed by the supplier. Radiolabelled proteins were resolved in SDS-PAGE (Laemmli, 1970) and identified by autoradiography.

DNA sequencing. Plasmid DNA obtained from minipreparations was denatured at $37^{\circ} \mathrm{C}$ for $30 \mathrm{~min}$ in $200 \mathrm{~mm}-\mathrm{NaOH}, 0.2 \mathrm{~mm}$-EDTA, in a final volume of $20 \mu \mathrm{l}$. The DNA was neutralized by the addition of sodium acetate $(\mathrm{pH} \mathrm{5.5)}$ to a final concentration of $0.3 \mathrm{M}$. The DNA was precipitated with ethanol, pelleted, washed and dried. DNA sequencing was performed by the dideoxy chain-termination method (Sanger et al., 1977) with a T7 DNA sequencing kit (Pharmacia) according to the supplier's instructions. $5^{\prime}-\left\{\alpha^{-35}\right\}$ Deoxyadenosine thiotriphosphate $\left[>1000 \mathrm{Ci} \mathrm{mmol}^{-1}\left(>37 \mathrm{TBq} \mathrm{mmol}^{-1}\right)\right]$ was obtained from NEN-Du Pont.

Amino acid sequence analysis. All alignments of the amino acid sequence derived from the nucleotide sequence were performed using the Multalin computer program (Corpet, 1988). The hydrophobic profile (window size: 7 amino acids) was calculated according to Eisenberg et al. (1984).

\section{Results and Discussion}

\section{Bacteriocin production}

$S$. marcescens $\mathrm{N} 28 \mathrm{~b}$ had bacteriocinogenic activity. This could be shown both on solid media (overlay test) and in broth cultures. The bacteriocinogenic activity was inducible by mitomycin $\mathrm{C}$ and could be detected in the cytoplasmic and extracellular fractions of exponentially growing cultures $2.5 \mathrm{~h}$ after induction. Without induction no bacteriocinogenic activity was detectable in exponentially growing broth cultures, although bacteriocinogenic activity could be detected in non-induced overnight cultures. So, the behaviour of this bacteriocin was similar to the $S$. marcescens bacteriocin L (Foulds \& Shemin, 1969).

\section{Localization of the bacteriocin genes}

Since most colicins are plasmid encoded, the plasmid profile of $S$. marcescens $\mathrm{N} 28 \mathrm{~b}$ was studied. A $3 \mathrm{~kb}$ plasmid was detected in this strain. This plasmid turned out not to be related to bacteriocin production, since cured strains still remained bacteriocinogenic and E. coli $5 \mathrm{~K}$ transformed with this plasmid did not produce bacteriocin (data not shown). Using different methods of plasmid preparation no other plasmids could be
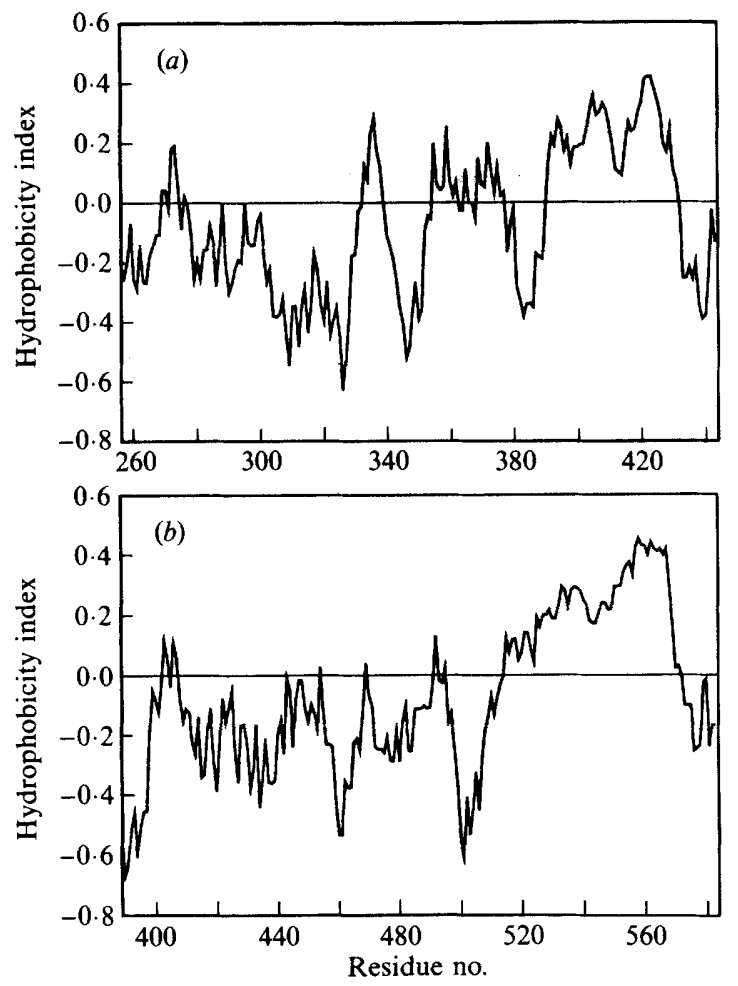

Fig. 5. Hydrophobicity analysis (Eisenberg et al., 1984) of the carboxyterminal part of bacteriocin 28b (last 194 amino acid residues) (a) and of the pore-forming domain of colicin A $(b)$.

detected, suggesting that the $S$. marcescens $\mathrm{N} 28 \mathrm{~b}$ bacteriocin could be chromosomally encoded.

\section{Cloning of the bacteriocin genes}

A genomic library of $S$. marcescens N28b DNA was constructed using plasmid pBR 328 as a vector. E. coli $5 \mathrm{~K}$ was transformed with the genomic library. From about 2000 clones screened two clones were found to produce bacteriocin. The two recombinant plasmids were purified and characterized. As shown in Fig. 1, both recombinant plasmids (pBA189 and pBA289) shared a region of DNA of about $9.5 \mathrm{~kb}$. Several subclones were constructed from plasmid pBA289, either by removing restriction fragments or by unidirectional deletion with Exonuclease III and Mung bean nuclease. Each subclone was tested for bacteriocin production (Fig. 1). The results indicated that the genes encoding $S$. marcescens $\mathrm{N} 28 \mathrm{~b}$ bacteriocin are located in a region of about $2 \cdot 0 \mathrm{~kb}$.

\section{Renaturation of bacteriocin after SDS-PAGE}

Several proteins, including bacteriocin $\mathrm{L}$, have been shown to be renaturable after SDS-PAGE (Lacks \& Springhorn, 1980; Foulds, 1972). To test the behaviour of 


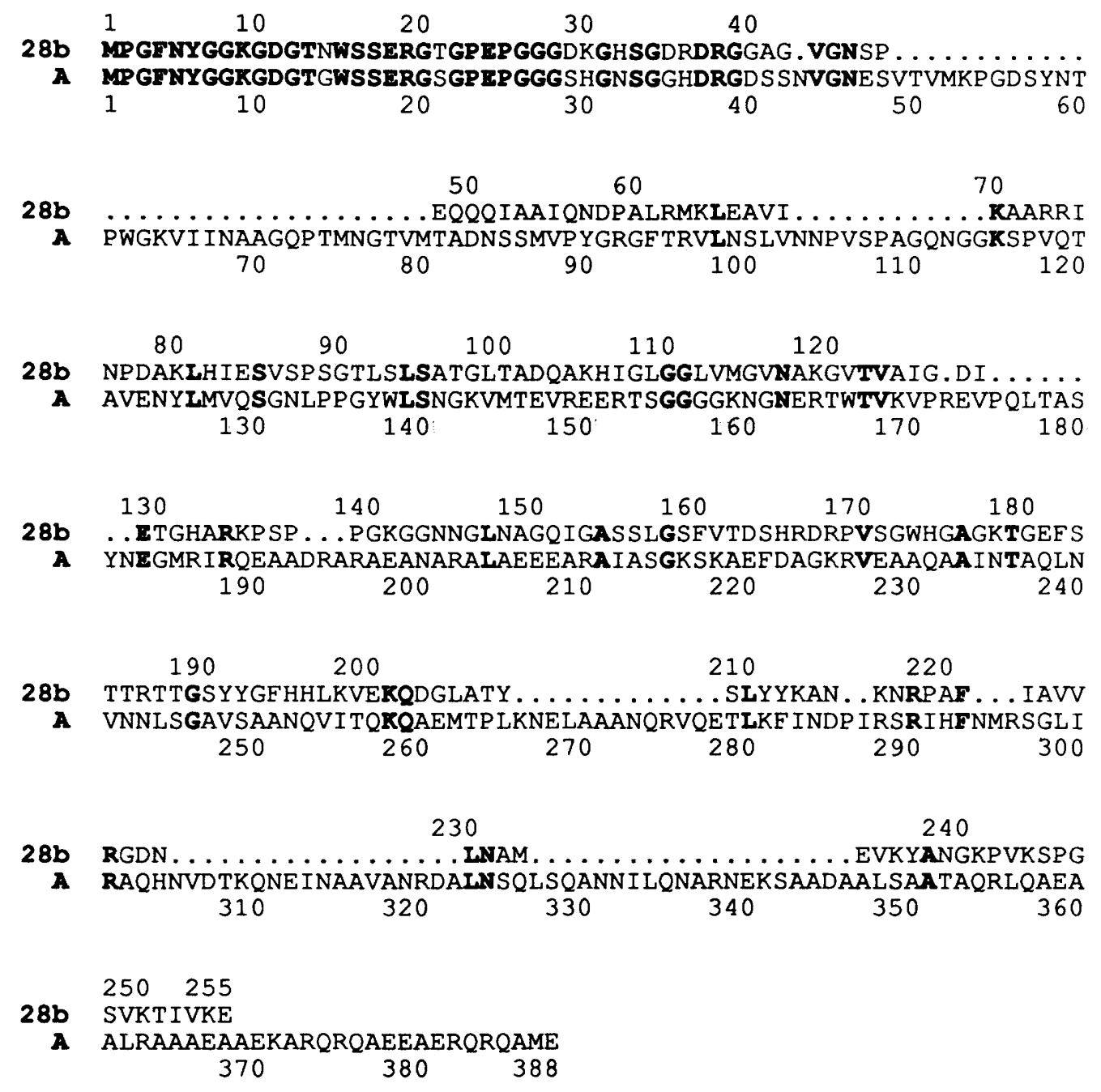

Fig. 6. Alignment of the amino acid sequences of the amino-terminal part of bacteriocin $28 \mathrm{~b}$ (first 255 amino acid residues) and colicin A (first 388 amino acid residues). The Multalin computer program (Corpet, 1988) was used. Identical amino acid residues are shown in bold type.

bacteriocin 28 b, sonicated cell-free extracts of $E$. coli 5K(pBA189) and crude extracellular bacteriocin preparations from induced $S$. marcescens $\mathrm{N} 28 \mathrm{~b}$ cultures were subjected to SDS-PAGE; the gels were then sliced into $5 \mathrm{~mm}$ slices, protein was eluted in $50 \mathrm{~mm}$-phosphate buffer (pH 7.0) and bacteriocinogenic activity was assayed. Bacteriocin $28 \mathrm{~b}$ was renaturable, since protein from one eluted slice was still bacteriocinogenic (data not shown). When the protein from the eluted bacteriocinogenic slice was subjected to SDS-PAGE and stained with Coomassie Brilliant Blue R-250 protein bands were located in the 30 to $50 \mathrm{kDa}$ region (see Fig. $3 a$, lane 3).

\section{Partial purification of the bacteriocin}

Crude extracellular bacteriocin preparations from $S$. marcescens N28b were applied to a QAE-Sephadex column previously equilibrated with $50 \mathrm{~mm}$-phosphate buffer (pH 8.0). Chromatographic separation was accomplished under starting conditions and bacteriocin activity was found in the void volume. The pooled void volume fractions from the QAE-Sephadex column were applied to an SP-Sephadex column previously equilibrated with $50 \mathrm{~mm}$-phosphate buffer $(\mathrm{pH} 8 \cdot 0)$. The column was washed sequentially with starting buffer, buffer containing $0.1 \mathrm{M}-\mathrm{NaCl}$, and buffer containing $0.2 \mathrm{M}-$ $\mathrm{NaCl}$ ( $\mathrm{pH} \mathrm{8.0)}$. Bacteriocinogenic activity eluted as a single peak with phosphate buffer containing $0.1 \mathrm{M}$ $\mathrm{NaCl}$ (Fig. 2). The pooled fractions from the SPSephadex column were dialysed, lyophilized, and subjected to SDS-PAGE (Fig. $3 a$, lane 4). Two polypeptide bands were found, with molecular masses of 45 and $17 \mathrm{kDa}$. Since SDS-PAGE of eluted gel slices containing bacteriocinogenic activity showed polypeptide bands in 


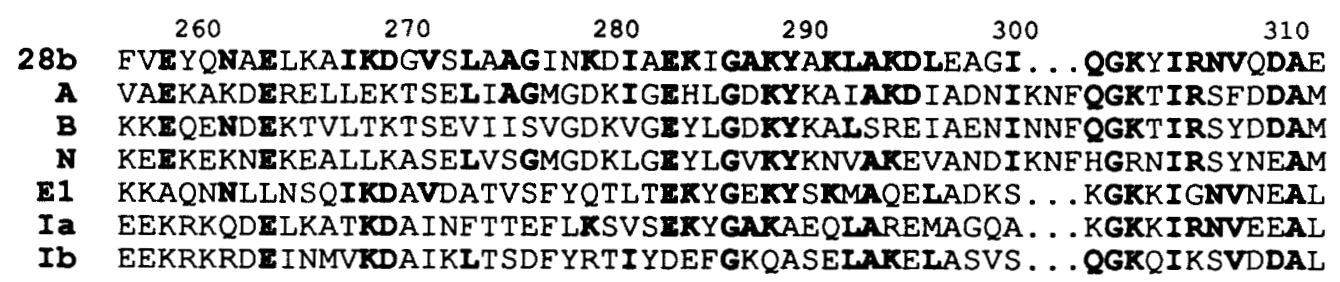

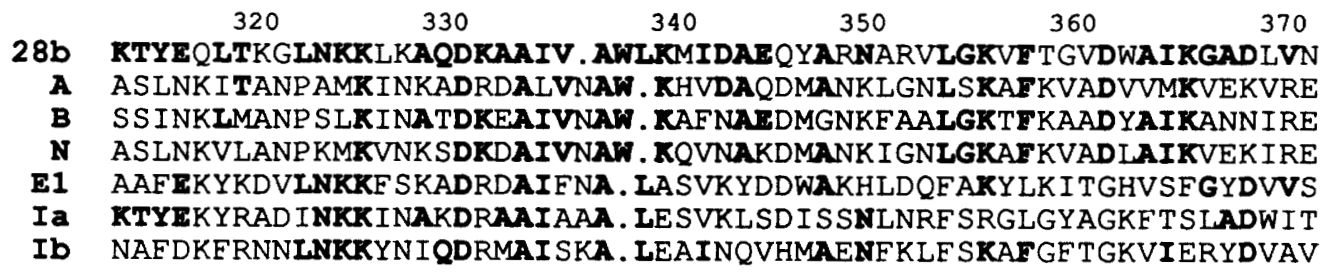

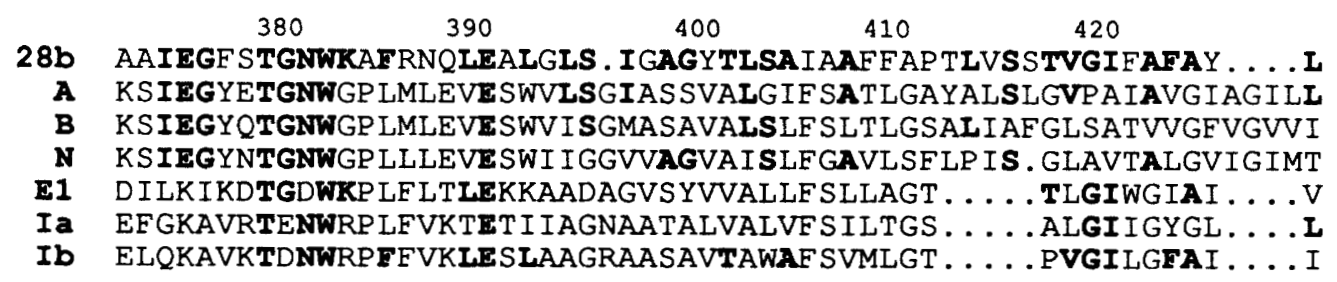

\begin{aligned} 28b & \multicolumn{1}{c}{430} \\ A & FWATSYIDAERAGELEKWVADL \\ B & AAVVGALIDDKEADALNNEIIRPAH \\ N & ISYLSSEIDAKEVDELNHKIIK \\ $\mathbf{E 1} &$ TGILCSYIDKNKLNTINEVLGI \\ Ia & MAVTGALIDESLVEKANKEWGI \\ Ib & MAAVSALVNDKFIEQVNRLIGI \end{aligned}

Fig. 7. Alignments of the amino acid sequences of the carboxy-terminal part of bacteriocin $28 \mathrm{~b}$ (194 amino acid residues) and the poreforming domains of colicins A, B, N, E1, Ia and Ib. The Multalin computer program (Corpet, 1988) was used. Bacteriocin $28 \mathrm{~b}$ amino acid residues identical to one or more from the other colicins are shown in bold type.

the 30 to $50 \mathrm{kDa}$ region, it was concluded that the $45 \mathrm{kDa}$ band corresponds to bacteriocin 28b. Moreover, a ${ }^{[35}$ S]methionine-labelled polypeptide of molecular mass $45 \mathrm{kDa}$ was detected in the in vitro products programmed by pBA. 290 DNA (the smallest subclone from pBA189 still conferring bacteriocinogenic activity), but not in the in vitro products programmed by pSK DNA (Fig. $3 b$ ). Taken together, these results suggested that the $28 \mathrm{~b}$ bacteriocin had been cloned in $E$. coli. Since the $17 \mathrm{kDa}$ polypeptide appears in the partial purified bacteriocin, but not in the in vitro transcription/translation system, most probably this polypeptide is not related to the bacteriocin.

\section{Nucleotide sequence of the $S$. marcescens bacteriocin structural gene (bss)}

A set of recombinant plasmids was used to determine the nucleotide sequence of the bss gene. A sequence of
$1568 \mathrm{bp}$ was determined (Fig. 4). The size of the bss open reading frame was $1347 \mathrm{bp}$. A putative ribosomebinding site was found $9 \mathrm{bp}$ upstream of the bss gene. No -10 or -35 sequences were found in the $75 \mathrm{bp}$ sequenced upstream of the open reading frame. An inverted repeat sequence was found after the stop codon. This inverted repeat sequence could be the transcription terminator of the bss gene.

\section{Analysis of the deduced bacteriocin amino acid sequence}

The predicted product of bss gene is a 449-amino-acid polypeptide with a calculated molecular mass of $47.5 \mathrm{kDa}$, which is close to the $45 \mathrm{kDa}$ value obtained from the partially purified bacteriocin. Inspection of the predicted amino acid sequence reveals a glycine- and proline-rich amino-terminal region. The carboxyterminal region is rich in lysine residues and contains a stretch of $\mathbf{4 4}$ uncharged hydrophobic amino acid residues 
flanked by acidic residues. This feature is also found in the carboxy-terminal part of the pore-forming colicins. According to hydrophobicity profiles, this stretch of sequence could be a membrane-spanning sequence (Pattus et al., 1990). The hydrophobicity profile of the carboxy-terminal part of bacteriocin $28 \mathrm{~b}$ shows a high degree of similarity to the corresponding domain of colicin A (Fig. 5). The amino-terminal amino acid sequence alignment of bacteriocin $\mathrm{N} 28 \mathrm{~b}$ and colicin $\mathrm{A}$ (Fig. 6) shows a high degree of similarity in the first 45 residues, with 35 identical residues. The carboxyterminal amino acid sequence alignment of bacteriocin $28 \mathrm{~b}$ (from amino acid 256 to 449 ) to the pore-forming domains of several colicins (Fig. 7) also shows a significant degree of similarity. The similarity is not very strong but is spread throughout the entire carboxyterminal sequence: $60 \%$ of the bacteriocin $28 \mathrm{~b}$ residues are identical to one or more from the other colicins, although the level of similarity to each colicin is only 23 to $30 \%$. On the basis of sequence similarity of the carboxy-terminal amino acid sequence (pore-forming domain), colicins have been grouped in two families, the colicin El family (including colicins E1, Ia and Ib) and the colicin A family (including colicins A, B and N) (Pattus et al., 1990). Bacteriocin 28b appears to be in an intermediate position between the colicin $\mathrm{A}$ and colicin El families. These results suggest that bacteriocin $28 \mathrm{~b}$ has a pore-forming ability and that this could be the killing mechanism of this bacteriocin.

This work was supported by grant PB 90-0468 from Comision Interministerial de Ciencia y Tecnología (CICYT). Spain. M.B.V. was supported by a fellowship from the Generalitat de Catalunya. S.F. was supported by a PFPI fellowship from the Spanish M.E.C.

\section{References}

BUllock, W. O., Fernandez, J. M. \& Short, J. M. (1987). XL1-Blue: A high efficiency plasmid transforming recA Escherichia coli strain with beta-galactosidase section. Biotechniques 5, 376-379.

CORPET, F. (1988). Multiple sequence alignment with hierarchical clustering. Nucleic Acids Research 16, 10881-10890.
De Graaf, F. K. \& Oudega, B. (1986). Production and release of cloacin DF13 and related colicins. Current Topics in Microbiology and Immunology 125, 183-205.

EisenberG, D., SchWarz, E., Komaromy, M. \& Wall, R. (1984). Analysis of membrane and surface protein sequences with the hydrophobic moment plot. Journal of Molecular Biology 179, 125142.

Foulds, J. (1972). Purification and partial characterization of a bacteriocin from Serratia marcescens. Journal of Bacteriology 110, 1001-1009.

Foulds, J. \& Shemin, D. (1969). Properties and characteristics of a bacteriocin from Serratia marcescens. Journal of Bacteriology 99, 655660.

Gargallo-Viola, D. V. (1989). Enzyme polymorphism, prodigiosin production, and plasmid fingerprints in clinical and naturally occurring isolates of Serratia marcescens. Journal of Clinical Microbiology 27, 860-868.

Juarez, A., Hartlein, M. \& Goebel, W. (1984). Study of regulation and transport of hemolysin by using fusion of $\beta$-galactosidase gene (lacZ) to hemolysin genes. Journal of Bacteriology 160, 161-168.

LACKS, A. S. \& SpringhorN, S. S. (1980). Renaturation of enzymes after polyacrylamide gel electrophoresis in the presence of sodium dodecyl sulfate. Journal of Biological Chemistry 255, 7467-7473.

LAEMMLI, U. K. (1970). Cleavage of structural proteins during the assembly of the head of bacteriophage T4. Nature, London 227, 680685 .

Maniatis, T., Fritsch, E. F. \& Sambrook, J. (1982). Molecular Cloning. A Laboratory Manual. Cold Spring Harbor, NY: Cold Spring Harbor Laboratory.

OLIVER, D. (1985). Protein secretion in Escherichia coli. Annual Review of Microbiology 39, 615-644.

Pattus, F., Massotte, D., Wilmsen, H. U., Lakey, D., Tsernoglou, D., TuCKer, A. \& PARKer, M. W. (1990). Colicins: prokaryotic killer-pores. Experientia 46, 180-192.

PugsLey, A. P. (1988). Protein secretion across the outer membrane of Gram-negative bacteria. In Protein Transfer and Organelle Biogenesis, pp. 607-652. Edited by R. C. Das \& P. W. Robbins. Orlando, Florida: Academic Press Inc.

Pugsley, A. P. \& Oudega, B. (1987). Methods for studying colicins and their plasmids. In Plasmids, a Practical Approach, pp. 105-161. Edited by K. G. Hardy. Oxford: IRL Press.

REGUÉ, M. \& WU, H. C. (1988). Synthesis and export of lipoproteins in bacteria. In Protein Transfer and Organelle Biogenesis, pp. 587-606. Edited by R. C. Das \& P. W. Robbins. Orlando, Florida : Academic Press.

SANGer, F., Nicklen, S. \& Coulson, A. R. (1977). DNA sequencing with chain-terminating inhibitors. Proceedings of the National Academy of Sciences of the United States of America 74, 5463-5467.

Traub, W. H. (1980). Bacteriocin and phage typing of Serratia. In The Genus Serratia, pp. 79-100. Edited by A. Graevenitz \& S. J. Rubin. Boca Raton, Florida: CRC Press.

WALKER, G. C. (1987). The SOS response of Escherichia coli. In Escherichia coli and Salmonella typhimurium: Cellular and Molecular Biology, vol. 2, pp. 1346-1357. Edited by F. C. Neidhardt. Washington D.C.: American Society for Microbiology. 